\title{
Publisher Correction: Double mimicry evades tRNA synthetase editing by toxic vegetable-sourced non-proteinogenic amino acid
}

\author{
Youngzee Song ${ }^{1}$, Huihao Zhou ${ }^{1,5}$, My-Nuong Vo1, Yi Shi ${ }^{1}$, Mir Hussain Nawaz ${ }^{1,6}$, Oscar Vargas-Rodriguez ${ }^{2}$,
} Jolene K. Diedrich ${ }^{3}$, John R. YatesIII (10 ${ }^{3}$, Shuji Kishi ${ }^{4}$, Karin Musier-Forsyth ${ }^{2}$ \& Paul Schimmel,4

Correction to: Nature Communications https://doi.org/10.1038/s41467-017-02201-z, published online 22 December 2017

In the original version of this Article, extraneous text not belonging to the article was accidentally appended to end of the first paragraph of the discussion. This error has now been corrected in both the PDF and HTML versions of the Article.

Published online: 13 March 2018

\begin{abstract}
(c) (i) Open Access This article is licensed under a Creative Commons Attribution 4.0 International License, which permits use, sharing, adaptation, distribution and reproduction in any medium or format, as long as you give appropriate credit to the original author(s) and the source, provide a link to the Creative Commons license, and indicate if changes were made. The images or other third party material in this article are included in the article's Creative Commons license, unless indicated otherwise in a credit line to the material. If material is not included in the article's Creative Commons license and your intended use is not permitted by statutory regulation or exceeds the permitted use, you will need to obtain permission directly from the copyright holder. To view a copy of this license, visit http://creativecommons.org/licenses/by/4.0/.
\end{abstract}

(C) The Author(s) 2018

\footnotetext{
${ }^{1}$ The Scripps Laboratories for tRNA Synthetase Research and the Department of Molecular Medicine, The Skaggs Institute for Chemical Biology, The Scripps Research Institute, 92037 La Jolla, CA, USA. ${ }^{2}$ Department of Chemistry and Biochemistry, Center for RNA Biology, The Ohio State University, Columbus, $\mathrm{OH} 43220$, USA. ${ }^{3}$ Department of Molecular Medicine, The Scripps Research Institute, La Jolla, CA 92037, USA. ${ }^{4}$ The Scripps Laboratories for tRNA Synthetase Research and Department of Molecular Medicine, The Scripps Research Institute, Jupiter, FL 33458, USA. ${ }^{5}$ Present address: Research Center for Drug Discovery, School of Pharmaceutical Sciences, Sun Yat-sen University, 510006 Guangzhou, China. ${ }^{6}$ Present address: Department of Chemistry, New York University, PO Box 129188 Abu Dhabi, United Arab Emirates Correspondence and requests for materials should be addressed to P.S. (email: schimmel@scripps.edu)
} 